\title{
Shaun Tan's The Red Tree (2001): A Visual Reading of A Postmodern Picturebook
}

\author{
Marwa Essam Eldin Fahmi \\ Assistant Professor, Faculty of Foreign \\ Languages and Translation, Misr University \\ for Science and Technology, Egypt
}

\begin{abstract}
The present study seeks to examine the poetics of the visual narrative art in a postmodern picturebook as exemplified in Shaun Tan's The Red Tree (2001). The Red Tree illustrates a fragmented journey through a gloomy world. The text is bare and matches the dim and surreal illustrations. The Red Tree is a postmodern visual narrative in tenor and form appealing to the resourcefulness of the child reader. The subject matter of the visual narrative is the visual narrative itself, i.e. fiction about fiction which celebrates the floating of meanings, the boundary-breaking indeterminacy and the counterpointing relationship between the text and the illustrations. The postmodern picturebook, unlike traditional picturebooks, does not seek to deliver a specific meaning, but rather provides the child reader with an experience of exploring an array of possible meanings. This study seeks to explore the notion of the child reader as a co-author of a postmodern
\end{abstract}

picturebook in an endeavor to interpret the visual narrative's paralinguistic cues. With this rationale, The Red Tree is a picturebook without a specific narrative which follows a red-haired girl as she wonders aimlessly through a series of selfcontained, highly detailed surreal landscapes accompanied by a vague and minimal thread of text, thus, the illustrations are purposefully open to interpretations and are mostly quite surreal in both the stylistic approach and the subject matter which is characteristic of postmodern texts. Therefore, it is my attempt to pursue the metalanguage of children's postmodern picturebook, a genre of literature worthy of serious analysis and investigation. The current study explores the visual syntax of the illustrations to construct a visual discourse through 'reading images' in a postmodern children's picturebook.

Keywords: Postmodern Picturebooks, Surrealist Visuals, Visual Criticism, Visual Ecology, Visual Semiotics 


\section{Shaun Tan's The Red Tree (2001): A Visual Reading of A Postmodern Picturebook}

Marwa Essam Eldin Fahmi

\section{Introduction}

\subsection{Aim and Scope}

The study has been triggered by the common assumption that children are unsophisticated and thus are unable to interpret complex texts. The rebut of such an assumption relies on David Lewis's elucidation - in Reading Contemporary Picturebooks (2001) - that children's literature has always reflected "the societal values, attitudes and knowledge of the historical period within which it was created" (87). This asserts the "transactional relationship" - to use Rosenblatt's description (14) between the child reader and the narrative so as to fill in "textual gaps": "all stories are built upon gaps - writers and picture book maker cannot describe, explain or show everything" (Lewis 96). Actually, young readers nowadays are familiar with nonlinear ways of reading and, therefore, they are more capable of dealing with postmodern sensibility than the adults who are not yet well-acquainted with multimedia workings for example in games and animations: "Literacy in the $21^{\text {st }}$ century means thinking critically, making sense of a bombardment of media sources, negotiating multiple digital literacy, and making choices about what to read and how to go about reading it" (Anstey 447). Bette Goldstone reinforces the great potentiality of what is called the "point-and-click culture" in which information comes from "bytes and text fragments that do not follow a linear, leftto right sequence" (367). This marks the remarkable potential of postmodern picturebooks to educate and entertain while being indulged in reading or decoding complex images by "manipulating format to push content beyond the protective walls of childhood innocence" (Kiefer 19).

Following David Lewis's rationalization, I use the compound word 'picturebook' to "describe the compound nature of the artefact itself" and to examine it "as a whole" so as to display the word-image tension (ix) in opposition to traditional picture-books with one single meaning. My premise ideologically and aesthetically - is formed by postmodern critiques of Romantic and Modernist beliefs that self grows with innate potentiality. Postmodernism challenges this assumption insisting "on the self - as construct - a fragmented play of surfaces where any sense of coherence or integration is illusory at best, a violent repression at worst" (Coats 76). Within this raison d'être, the current study adopts the argument that childhood's vision has moved from Romantic notion of nostalgia that depicts the innocent child who acts as a fetish to ward off fears regarding death, decay and loss to the sophisticated child who exposes issues regarding vulnerability, abuse, social injustice and nihilism. The Red Tree (2001) foregrounds the bleak philosophical but playful pictorial conventions of 
postmodernism, that is, the rejection of a linear reading, the denunciation of one single interpretation and the embrace of the possibility of multiple readings of the visuals.

The current paper seeks to establish The Red Tree as a postmodern picturebook since it follows the features of postmodernity that is "marked by a view of the human world as irreducibly and irrevocably pluralistic, split into a multitude of sovereign units and sites of authority, with no horizontal or vertical order, either in actuality or in potency" (Italics mine, Bauman 35). The Red Tree is a postmodern visual narrative in tenor and form appealing to the resourcefulness of the child reader. The subject matter of the visual narrative is the visual narrative itself, i.e. fiction about fiction which celebrates the floating of meanings, the boundary-breaking indeterminacy and the subversive relationship between the text and the illustrations to examine the pivotal questions below:

- What is a picture-book? What is its position in relation to Visual Criticism?

- What are the strategies of postmodern picturebooks?

- Is there a symbiotic relationship between the form and the content in Tan's The Red Tree?

- Is postmodern picturebook an inclination rooted in the form itself or a preference of the author-illustrator's stylistic technique that semiotically deconstructs the structure of the visual and lexical signs?

The purpose of these questions is to set The Red Tree as a postmodern picturebook to illustrate how a purposeful absence of apparent meaning in picturebooks has the potential to allow limitless interpretations of a single text. Thereby, the paper highlights the definition proposed by Ansety who describes the postmodern picturebooks as "a medium designed to interrupt reader's expectations by allowing multiple interpretations to dominate" (447). In The Red Tree, Tan subverts intentionally the traditional dynamics of the relationship between the illustrator and the child reader of the picturebook by creating a complex visual narrative which displays a general absence of clear accessible meaning, thereby, allowing the child reader to actively participate in the meaningmaking process.

\subsection{A Picture-Book: A Signifier of Visual-Verbal Codes}

"As an art form it hinges on the interdependence of pictures and words, on the simultaneous display of two facing pages, and on the drama of the turning of the page" (Bader 1).

Essentially, a picture-book provides the child reader with a visual experience through the outstanding use of expressive illustrations, storyline, setting and characterization. The most distinctive feature of a picture-book is the combination or interaction between the visuals and the text. Yet, the outstanding question that arises from the abovementioned quotation is the question of domination; which is the most powerful principal: the pictorial element or the lexical one. This foregrounds the broadest and limitless possibilities of the genre. This highlights Marantz's viewpoint: "A picture-book, unlike an illustrated book, is properly conceived of as a unit, a totality that integrates all the designated parts in a sequence in which the relationships 
among them - the cover, endpapers, typography, and pictures - are crucial to understanding the book" (3). Lewis notes that "an adequate theory of the picturebook must directly address the bifurcated nature of the form [word and pictures] and must account for the whole range of types and kinds including the metafictive" (1990: 141). Thereby, the picture-book, as a genre, relies heavily on the interaction of two separate yet integrated systems of signification.

The semantic/semiotic association enhances the understanding of both fiction and real world leading to pivotal experiences. Indeed, visuals add feelings and depth to the text and to the child reader's sensibility as well. This rationale is expressed by Suzanne Langer: "Imagemaking is the mode of our untutored thinking, and stories are its earliest products" (145). The construction of meaning is determined by the reader's role to decode the underlying message of the visual narrative in accordance to accumulated life experiences and cultural background.

Visual criticism - as a theory - grows out of the illustrator's or authorillustrator's choice of pictorial techniques and conventions, visual rhythms and patterns. Langer argues that artwork is an expression of the illustrator's thesis:

i.e something that takes shape as he articulates an envisagement of realities which discursive language cannot properly express what he makes is a symbol - primarily a symbol to capture and hold his own imagination of organized feelings, the rhythms of life, the forms of emotion. (392)
Multiple pictorial styles involve fresh perspectives and technical conventions regarding both content and form. Genova proposes a "meaning-expressing model" for style, acknowledging "a variety of sources ranging from psychological to cultural and aesthetic uses" emphasizing that style is the result of "unconscious as well as conscious choices" (324). The key point is that style enhances "symbolic meaning", that is, style and meaning are intermingled to display the illustrator's choice of technique expressive of his aesthetic experience. In Words about Pictures: The Narrative Art of Children's Picture Books (1988), Perry Nodelman pinpoints the 'ironic' relationship between the illustrations and the text: "when words and pictures combine, irony emerges from the way in which the incompleteness of each is revealed by the differing incompleteness of the other" (Italics mine, 222). This highlights the question of style which unfolds the artists' choices of paralinguistic conventions and sets "the proper basis for a theory of visual criticism in picture books" (Kiefer 1993: 76).

Color, line, shape, value, hue, saturation, gaze, angle and texture are signs of visual design that distinguishes the artist's visual syntax to communicate meaning. Herein lies the source of pleasure of a picture-book regarded as being "a provocative, sophisticated, cultural product" (Schwarcz 10). This underscores the hermeneutic potentiality of the genre within the paradigm of semiotics. A picture-book, as an experience, focuses on the transactional relationship between the reader and the text. This underlines the role of paralinguistic cues that make semiotics a 
highly developed epistemological, theoretical, and methodological framework for deconstructing the structure of lexical and visual signs epitomized in picture-books as communicative codes that work to assist the transference of meaning or to examine the means of signification.

Visual syntax describes the function of the image for building meaning through the reading of pictures and the signs they represent. Jewitt and van Leeuven regard both "word and image as one indivisible unit of analysis" (7) and this indivisible unit promotes the rise of multimodal text referred to as "any text whose meanings are realized through more than one semiotic code" (Jewitt and van Leeuven 183). The semiotic interpretation of the picture-book's interaction of the visual and the verbal codes is complex, yet it unfolds a flexible communication between the creator, the text and the child reader. Along with a central narrative, a picturebook includes front and back information such as title, copyright and dedication page. There is also a book design - the paratextual clues - displayed in the layout of each double page spread, the harmonious movement page to page, the choice and placement of type, the nature of the page and the size of the book itself. The manipulation of the whole physical space of the book can make for a closer relationship between the child reader and the represented central character. Recently, the picture-book has acquired many characteristics associated with Postmodernism promoting a new approach to interrogate the relationship between the pictures and the text. With the double-coded nature of the postmodern picturebooks, the act of visual communication has acquired a novel compositional layout of a page from leftto-right, or from center-to-margin; visual signs are expressed in terms of low modality and the shattering of linear narrative in which the visuals cannot be followed in a sequential realist manner.

\section{A Postmodern Picturebook: A Signifier of an 'Omnivorous' Artefact}
"The picturebook is thus emphatically not itself a genre. It is an omnivorous creature, ingesting, absorbing, co-opting preexistent genres - other ways of speaking, writing, picturing - in order to make its texts" (Italics mine, Lewis, 2001: 74).

Lewis defines Postmodernism as "the cultural and intellectual phenomena that has grown out of the rubble and that have blossomed since the 1960s in the form of buildings, paintings, works of literature and other forms and artefacts" (2001: 88). Stuart Sim concurs that Postmodernism is
a wide-ranging cultural movement which adopts $a$ skeptical attitude to many of the principles and assumptions that have underpinned Western thought and social life for the last few centuries. These assumptions, which constitute the core of what we call modernism, include a belief in the inevitability of progress in all areas of human endeavour, and in the power of reason, as well as a commitment to originality in both thought and artistic expression (Italics mine, 285). 
Thereby, Postmodernism is ideologically a clear denial of "the cultural certainties on which life in the West has been structured over the past couple of centuries" (Sim vii). Philip Rice and Patricia Waugh suggest that Postmodernism "wages war on totality throw[ing] into doubt the claims of any one discourse or story to be offering the truth about the world or an authoritative version of the real (Italics mine, 308). Geoff Moss proposes that "The result of this shift from the ways of modernism to postmodernism is an increased selfconsciousness in art and writing, an exploration of the limits and possibilities in art and of the past which informs it" (Italics mine, 55).

In traditional picture-books, the two codes of signification - the picture and the text- tend to complement one another creating a homogeneous text. The shift from traditional picture-books to postmodern ones underscores an important question that arises when considering the interchange of verbal and visual workings of picture-books: Where does the child reader look at first? At the illustrations or at the text? Nodelman provides an answer in what he calls the "rhythm of picture-book stories" (1988: 261). He explains that the image-word relationship is ambiguous and unsteady because "the small portions of text are constantly disrupted by the pictures which split them" (1988: 249). The text leads the child reader forward in the storyline while the pictures illustrate how a definite dramatic situation looks like at an exacting instant in the story, namely, the text pushes further, but the picture holds the child reader back. This ambiguous interplay challenges the child readers "to bring their own answers, their own resolutions to the works, and to join forces with the author/illustrators in creating the scenario, the story, and the interpretation" (Nikolajeva and Scott 2001: 259). This pinpoints the nature of the "interrogative text" as proposed by Stephens:

[It] include a tendency to employ a range of discourses which may function oppositionally or dialectically, effecting a multiplicity of unresolved points of view on both micro-discoursal and macro-discoursal levels. Such an element of indeterminacy may operate in conjunction with a tendency to employ textual strategies which undermine the illusion of fictionality by drawing attention to the nature of the text as text. (123-124)

This is pertinent to Hutcheon's view of metafiction which foregrounds its "fiction making processes" as openly contesting realism, "for it embodies its own theories, demands to be taken on its own terms" (39). With this rationale, The Red Tree can be regarded as a postmodern interrogative visual narrative which finds no satisfaction or pleasure in the storyline itself, "but it is interested in the nature of fiction and the process of storytelling, and it employs metafictive devices to undermine the unreflective and naïve reading of stories" (Italics mine, Lewis 2001: 93-94).

\section{The Red Tree (2001): A Signifier of Visual 'Ecology'}

Commenting on Tan's oeuvre, L. Hunter states that "an air of uncertainty seems to be the main rhetoric surrounding Tan's work, relative to both the content of his picturebooks, as well as their ability to evade classification" (10-11). He also 
explains that "Tan's picturebooks work across boundaries, and while his work may take the form of picture books, they do not seem to fit within the traditional ideas concerning what 'children's literature' should be" (11). Tan's "surreal drawings" (Devos 18) are eloquent, poetic, sophisticated and dynamic. They do not only incorporate some elements of postmodernism, but they do enhance what Cherie Allan calls "postmodernesque" (24) picturebooks produced in the early years of the twenty-first century. Instead of challenging the worldwide truths advocated by postmodernism, this new postmodernesque genre challenges aspects of the postmodern world such as globalization, mass media, and consumerism that can lead to a nihilistic condition as exemplified in The Red Tree which depicts the existential mood of a nameless red-haired girl who rooms her outside world in a melancholic, absurd and grotesque manner. The Red Tree subverts the foundations of accepted modes of thought and experience so as to reveal the 'meaningless' of existence and the underlying 'abyss', 'void' or 'nothingness' on which any supposed security is envisaged to be precariously suspended.

The Red Tree signifies the postmodern essence of what Jean-François Lyotard regards as "incredulity towards metanarratives" (xxiv) encouraging the child reader's contribution in recreating the story acting as "co-author[s] of the [text]" - to use Roland Barthes's description (1457). In other words, The Red Tree can be viewed as a "radical change" (Dresang 19), a "construction" (Sipe 1998: 107), a "puzzle" (Nodelman and Reimer 298), and as a "processes of storytelling" (Lewis 2001: 92) in which the child reader is summoned to become critical "creators, interpreters and innovators" (Reynolds 35). Tan's mysterious illustrations create a provocative mood intended to trigger a kind of ontological strangeness, boundarybreaking indeterminacy, randomness and the disrupted narrative is at the heart of collage.

The examination of the aesthetic contemplation of The Red Tree utilizes Lewis's metaphorical concept of the ecology of the picturebook to highlight Tan's creative manipulation of page layout, color, collage, typeface and angle to ensure destabilization, anti-didactic stance and diverse interpretations of the pictures. Lewis's "ecological framework" describes the internal ecological system of the visual narrative within what he calls the "process framework":

Words and pictures are always and everywhere at work upon each other. Even the simplest picture book version of fairy tales have an inflection, an accent, an angle that would be missing were pictures not present $\ldots$ the picturebook is therefore just as much as $a$ process as it is a form of text we might refer to this process as 'picturing'. (Italics mine, 2001: 66-67)

On considering the picturebook as ecosystem, Lewis speculates "how the words and picturebooks act upon each other reciprocally, each one becoming the environment within which the other lives and thrives" (Italics mine, Lewis 2001: 54). Lewis's 'ecological' perspective can be envisioned in the diagram below: 


\section{Lewis's 'Process Framework'}

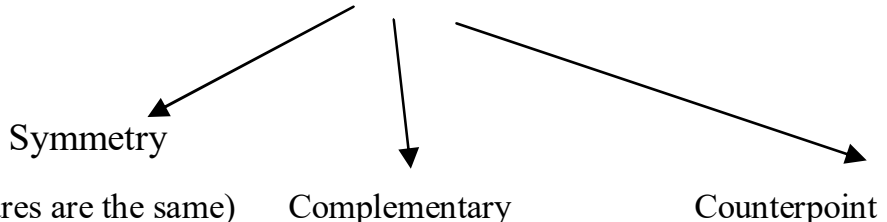

(Words and pictures are the same) Complementary

Counterpoint

(Words and pictures fill each other's gaps) (Words and pictures tell

Figure 1 different stories)

The notion of 'ecosystem' as a dynamic world helps understand "how the wordpicture relationship might shift and change, page by page and moment by moment" and appreciate "the heterogeneity that we can sometimes find with the picturebook" (Lewis 2001: 54).

The "process framework" is adopted to 'picture' the format of The Red Tree whose dense spreads resist closure and are open to diverse interpretations. It is noteworthy that the visuals take up the whole physical space of the pages. This suggests that the text is not easily contained to question the notion of the center. If there is no center, there can be no defined margins. John Stephens argues that "there are also special problems posed by texts which set out to deny any stable centre of potential meaning and hence imply a reader capable of multiple perspective" (55). This denial of a center allows the reader to establish multiple discourses as the child reader is required to rove the pages in order to find his/her focalizing point.

Nikolajeva and Scott comment on Hermeneutics as an approach to read images through the text and to read the text through the images: "Hermeneutic analysis starts with the whole, proceeds to look at details, goes back to the whole with a better understanding" (2001: 2). This pinpoints the "counterpointing" relationship between text and image: the "spatiotemporal relation is the only area in which words and pictures can never coincide. The picture, the visual text, is mimetic; it communicates by showing. The verbal text is diegetic; it communicates by telling" (Italics mine, Nikolajeva and Scott 2001: 26). This enhances a "close reading" (Nodelman 2008: 93) of the paratextual conventions to observe that "the words in a picturebook tend to draw attention to the parts of the pictures that we should attend to, whereas the pictures provide the words with a specificity - colour, shape, and form - that they would otherwise lack" (Lewis 2001: 35). Thereby, the child reader turns from the textual to the visual and back again "in an ever-expanding concatenation of understanding" (Nikolajeva and Scott 2001: 2). The examination of The Red Tree's paratext includes text-placement, page layout, font, title page and illustration style. The unique format lies in its zigzag visual narrative which echoes a loose interior monologue that reflects the desperate girl's inner thoughts, memories and reactions in a choppy text.

\subsection{The Paratextual Clues}

The function of the cover page is "a threshold that offers the world at large the possibility of either stepping inside or turning back" (Genette 2): 


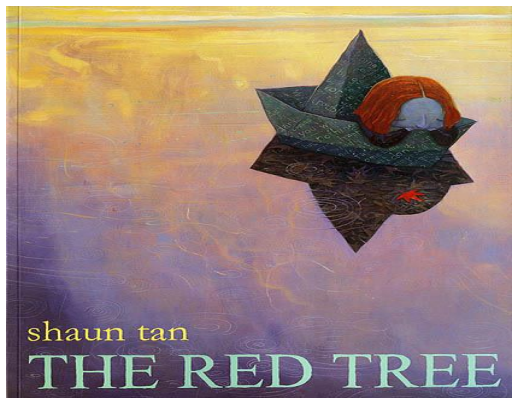

Figure 2: Cover Page

The nameless girl sees her reflection as a red leaf surrounded by whirlpools and the papery boat's reflection is the dark leaves can be regarded as the girl's gloomy life or ominous external world. This signifies the girl's visual journey into herself. The visual narrative is circular; the storyline begins and ends in the girl's bedroom, the text is minimal and each page is a distinct autonomous entity. The black dark and dry leaves - seen accumulated in the girl's bedroom - drive her to the outside world undertaking a journey of self-discovery delineated in self-contained spreads. The only link is a small red leaf that follows her in each surreal landscape creating a visual motif of the hope that awaits the red-haired girl even in her gloomiest and hard times.

Tan juxtaposes the grey frontpage and the endpage - bright with a red tree in the shape of a heart to signify the move from a dim reality depicted in somber sepia tones to a promising one:
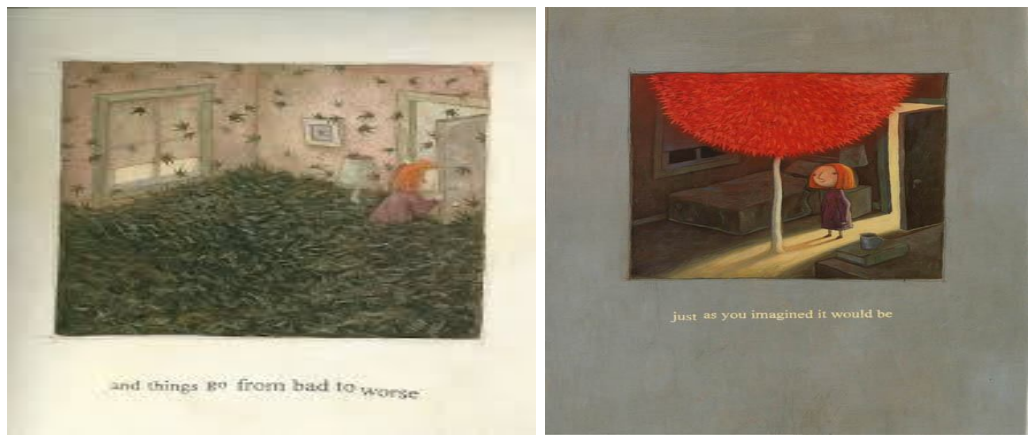

Figure 3: Front \& End pages

The tiny red seed of hope has burst "bright and vivid quietly waiting just as you imagined it would be"; as the text says. The endpage constitutes a "space between" (Genette 1) where the reader is neither outside nor yet inside the story. The concept of "peritext" (Higonnet 4) draws attention to the materiality of the book in order to provide a fresh textual meaning. The endpage marks the movement from the public space of the cover to the private world acting as a "stage curtain" (Sipe 2001: 23). This echoes J. Derrida's suggestion that the use of peritext makes the text "no longer the snug airtight inside of an interiority or an identity-to-itself" (35).

\subsection{The Counterpointing Tension of Abstract Text and Mysterious Images}

The Red Tree deploys the counterpointing tension of words and images. This counterpointing is regarded by Tan as "incompleteness" that "compels the reader to partake in the meaning- 
making process" (Tan 2011: 8). This textual gap is compared as "concentric waves" that spread out on the surface of the water: "It is not much different with a word, thrown by chance into mind, producing waves on the surface and in the depths. It provokes an infinite series of chain reactions, and as it falls, it evokes sounds and images, analogues and recollections, meaning and recollections, meanings and dreams in a movement that touches experience and memory, the imaginative and the unconscious" (Poesico 234). The nameless girl is never mentioned in the textual narrative which is set against vague fantasy images. She is present in all the spreads, but absent in the text. This vastness between words and visuals is delineated in disconnected unfamiliar and strange landscapes.

A postmodern picturebook explores a multitude of questions: "What is real? What is the story? The page? The book itself?" (Goldstone 364). The remarkable feature of postmodern text is its ontological enterprise of decentralization manifested in "the non-linearity, selfreferentiality, cynical tone and antiauthoritarian" (Goldstone 363-366). Lewis attributes these aesthetic features to the key tenets of a postmodern world exemplified in "fragmentation, decanonization, irony, [and] hybridization" (2001: 88-91). Goldstone pinpoints the major strategies of postmodern picturebooks: they do not follow a linear pattern; they are selfreferential; they have a skeptical or sarcastic tone; they urge the child reader to provide a myriad of meanings; they have textual gaps or ambiguities to be encoded; they are playful in terms of jokes, puns or irony; they have shifting viewpoints; they have multiple narratives; and they have jokes in the illustrations that are not present in the text (Goldstone 363).

These postmodern narrative strategies underscore the dominant feature of 'metafiction'. Margaret Mackey suggests that metafiction "fosters awareness of how a story works without intrusive didacticism" (Italics mine, 181). This rationale follows Patricia Waugh's definition of metafiction as: "writing which self-consciously and systematically draws attention to its status as an artefact in order to pose questions about the relationship between fiction and reality" (Italics mine, 2). Therefore, postmodern picturebooks are polysemic since the interpretations of the illustrations in relation to the linguistic aspects of the text are fluid.

The following spread depicts a huge bleeding fish - not mentioned in the text can be interpreted as a projection of the girl's inner emotions and perplexed state of mind since the fish is not seen by the rest of the pedestrians:

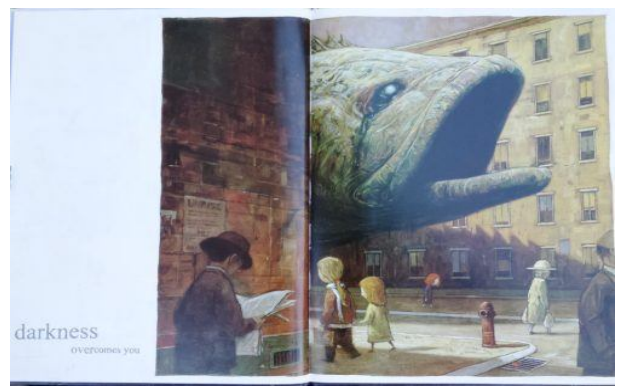

Figure 4

"You" and "darkness" are words that create bewilderment: what does darkness signify? Is it physical or an external threat or even a melancholic state of mind? The dissonance is created when words and pictures do not tell the same story presenting a satisfactory reading 
experience. Tan claims that "above and beyond any simple story or 'message', I believe that the personal reflections of the reader and far more important than those of an author" (2011: 8). It is obvious that the illustration dominates the spread dwarfing the faceless girl. As the giant tearful fish casts its shadow on the sad girl, the word "darkness" casts its own shadow onto "overcomes you". This is enhanced through the use of bold and large typeface to evoke feelings of threat, intimidation and menace.

\subsection{Disoriented Text-Placement}

Tan's disoriented text-placement is the most unique postmodern feature that defies rationalism and contributes apprehensive and unsettled feelings as exemplified in the dedication page which depicts dancing reversed letters of the picturebook's title and acts as a door into the visual narrative:

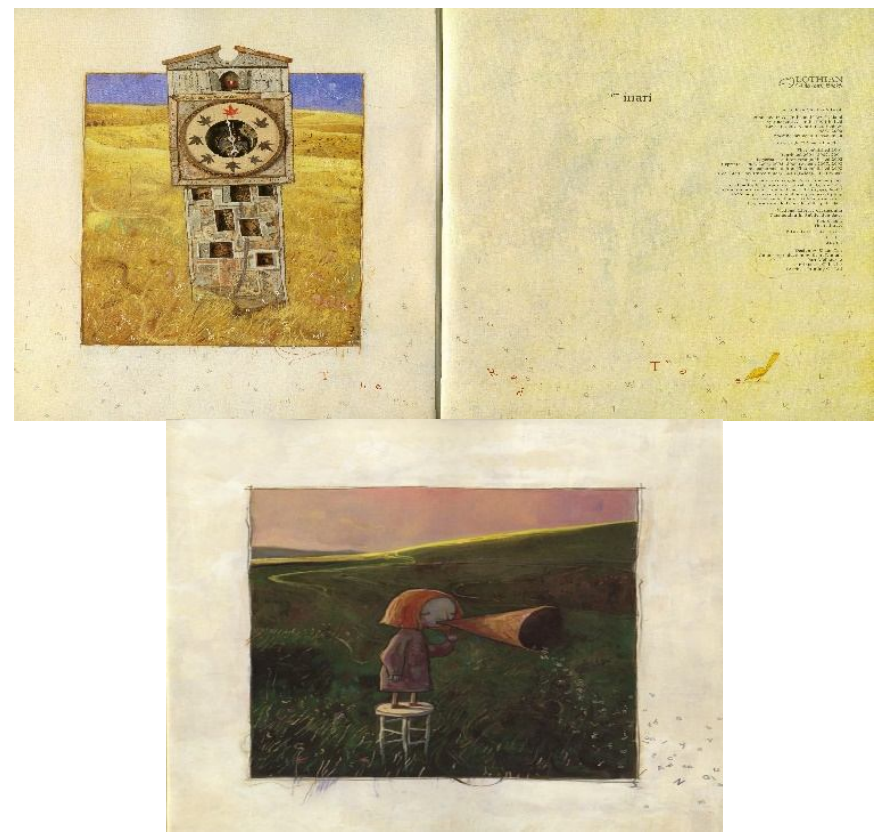

Figure 5

The small red leaf is depicted as twelve o'clock to signify a new day while the rest leaves are dark and dry to signify the harsh, dim past and the present. The girl speaks in a vast region with many paths through the loudspeaker, yet her internal words fall down randomly. This act intensifies the lack of communication from which the little girl suffers; nobody to hear, to sympathize, to pity.

The crucial question is how far do the size and the style of the typeface enhance the storyline visually? The placement of text serves as "a visual element and semiotic resource with its own meaning potentials" (Serfani \& Clausen 23). It is a carrier of meaning unto itself: 


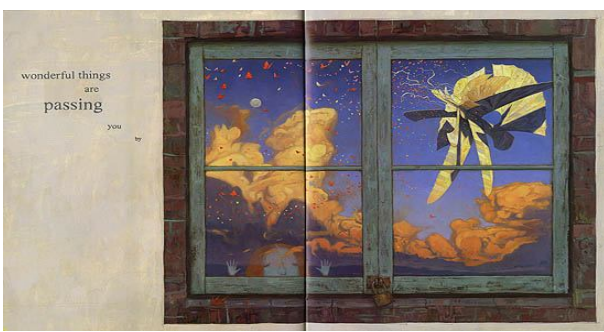

Figure 6

The textual placement floats slowly towards the illustration in a zigzag style and the large size of the word "Passing" increases to signify the huge regret that overwhelms the girl because she cannot enjoy life. The anxious restless girl and the red leaf epitomize the focalization of the whole visual narrative to exhibit her inner workings, morbid and melancholic feelings. In several visuals, she is depicted looking to the left of the page that stands for protection, safety and familiarity. The tiny red leaf is an echo of the girl's autumn-red-hair. The red hair establishes the girl as a different female protagonist who suffers from deep depression. Red manifolds two contradictory impressions: either as a transcendent symbol of optimism, hope, emotions and passion or as a danger and a threat.

\subsection{Manipulating a Comic Book Frame Format}

Tan communicates the theme of futile waiting in a highly artistic manner manipulating a comic book frame format:

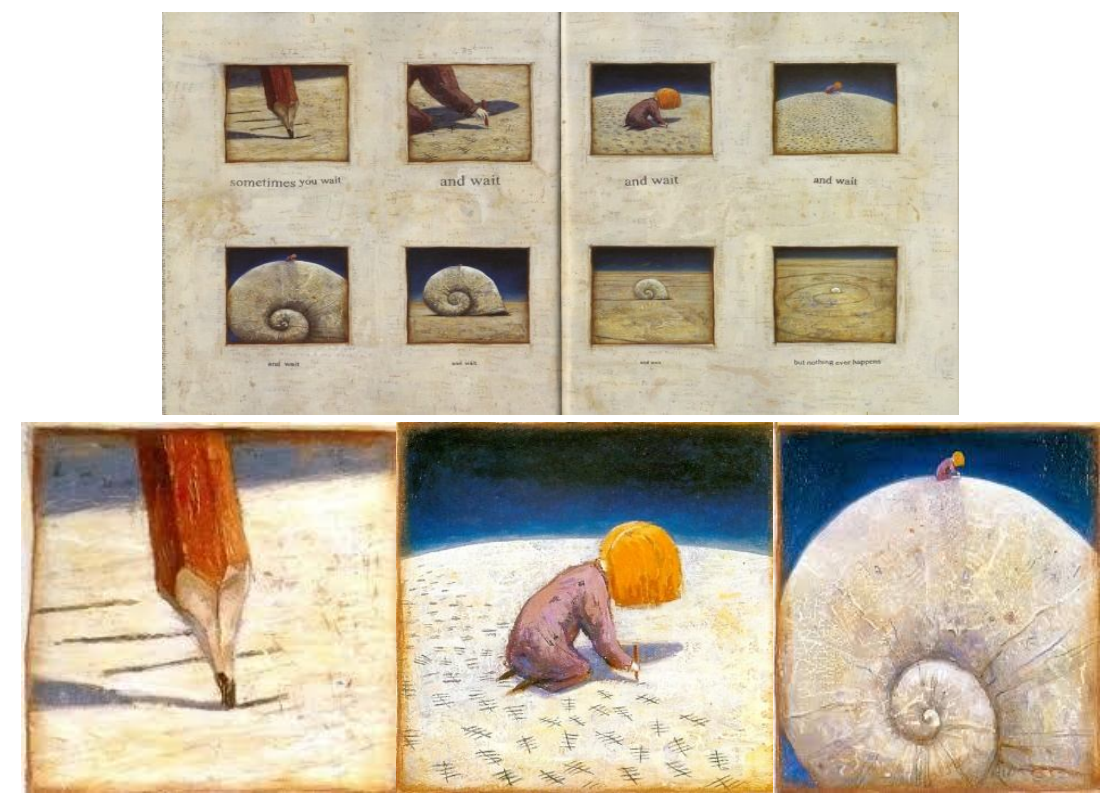

Figure 7

Tan splits the spread into eight smaller frames and each depicts the same scene of the monotonous act of waiting. The course of time is illustrated through the zoom out technique. The first scene foregrounds tightly the pencil drawing ticks. The long waiting is compared to snail shell. The nameless girl is atop a large snail shell and 
as the scene zooms out further, the shell is seen moving slowly in an endless spiral pattern. The text is repeated to emphasize this static act of waiting.

The meaning-making is expanded since the words create expectations for the images and the images create expectations for the words. This process is described as a "weaving" (Lewis 2001: 33) or even "synergy" (Sipe 1998: 98). The effect of the word-picture relationship is achieved through their "perceived interactions and transactions" (Sipe 1998: 99). Sipe explains the dynamics of the synergistic relationship between words and pictures. $\mathrm{He}$ speculates that the "total effect" depends on the text, the illustrations and the reciprocity between these two sign systems where "we adjust our interpretation of the pictures in terms of the words and our interpretation of the words in terms of the pictures" (1998: 103). It is also regarded as an "alchemy [where] typographical characters, marks, lines, colours, perspective and cleverly manipulated spaces - evoke not only sounds, but also tactile sensations, emotions and moods" (Poesico 224).

\subsection{The Focalization of the Visual Narrative and the Nihilistic Self}

The girl's dark emotional world is represented in an impressionistic tale through a series of lyrical tableaus: the fish looms over her alone, she is locked in a bottle alone, she acts as a clown playing with a miniature replica of her entity and she draws her own portrait from behind on the wall:

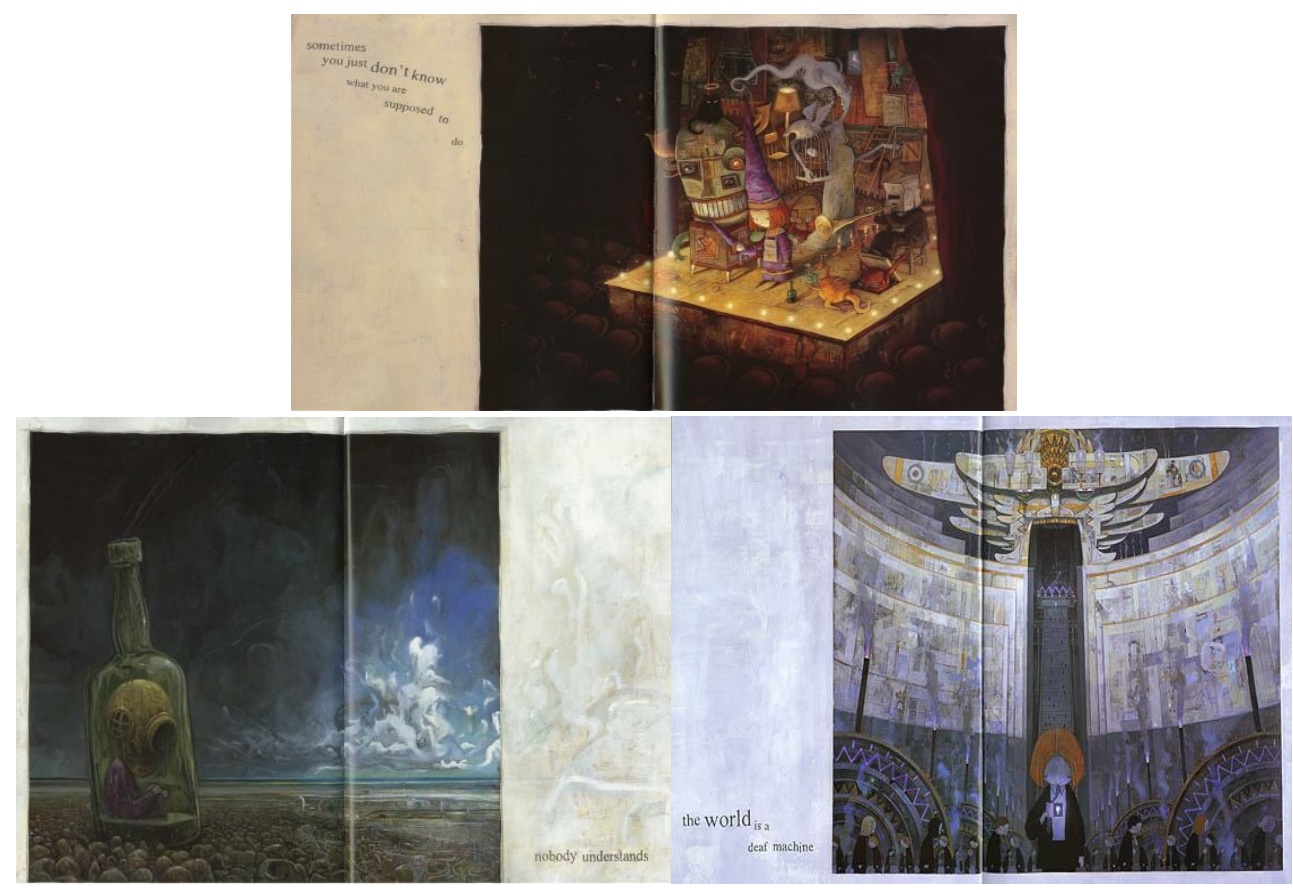

Figure 8 
These visuals dwarf the girl as if she was a speck of dust in a "deaf machine" world through the deployment of long shots. She wears a helmet and stuck in a bottle, yet there is a ray of hope visualized in white clouds. She is also seen in black costume carrying a small light glowing bulb in a low angle shot that signifies menace and danger. These visuals evoke her sense of estrangement, alienation and isolation since she wanders alone in a hostile world as symbolized in the scary storm, the fearful huge giant that looms on the horizon and awaits her at the end of the board game:

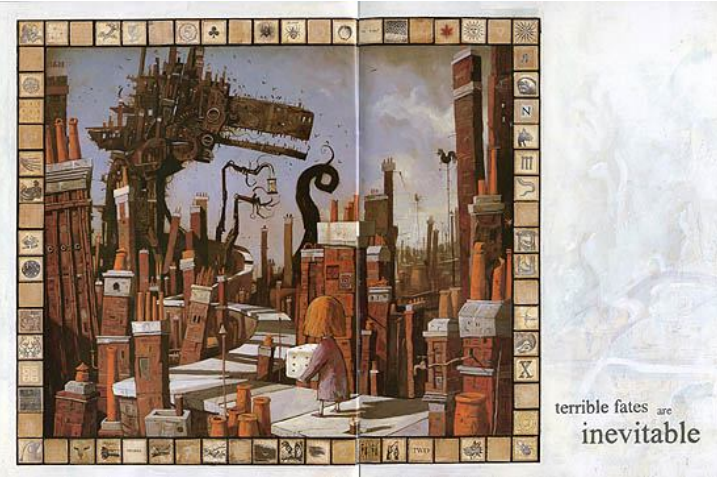

Figure 9

Fate is symbolized as a surreal board game and the girl is seen holding a dice which is an embodiment of "inevitable" in large font. This huge monstrous mechanical bird can evoke infinite interpretations; it can signify an authoritative figure such as an unfriendly teacher or a callous boss or even a coldhearted father. It can also be an embodiment of the modern dystopia or nihilistic world.
The Red-haired girl displays characteristics of existential postmodern individual. As an existential being, she is plagued by the absurdity of existence, the crisis of the self defeated by anguish and the dread of nothingness of human existence as exemplified in the use of WH-questions to allude to skepticism towards the value of existence:

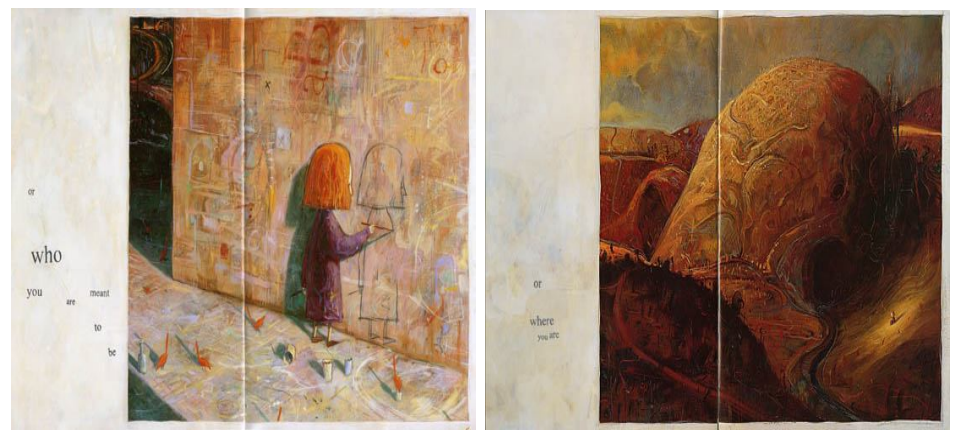

Figure 10 
The WH-questions in the visuals are a version of the existential question 'Why am I?' The zigzag text-placement mirrors the girl's inner turmoil. The two visuals signify the "abyssal nihilism" (Lyotard et al. 11) to indicate the negation of meaning that takes place when the field of existence becomes too wide and indeterminate" (Lyotard et al. 11). Postmodernism is "concerned with ontological questions - the theory of existence, and investigations into the nature of being and existence" (McHale 10). Nihilism is closely associated with the postmodern discourse to refer to the collapse of long-established values and the bankruptcy of Enlightenment ideals of rationality and progress, yet it does not keep the human being from asking questions about how to live and why in a complicated and fast world with technological changes and dominant social institutions. Tan renders "imaginary worlds which are both specific and at the same time universal and surreal representations of wordless longings and fears" (Hunt 11) and this surrealism enhances the child reader's expectations of meaning. Yet, this indeterminacy created by the absence of apparent meanings - allows the child reader to "construct text" from the abundance of signs.

\subsection{The Incorporation of Visual Collage}

Although the visual narrative begins and ends with traditional framed illustrations, Tan creates an "intraiconic text" - to borrow Nikolajeva's and Scott's term (2001: 118). The incorporation of visual collage is also referred to as an "intraiconic text" to describe "words appearing inside pictures and in some way commenting on or contradicting the primary verbal narrative" (Nikolajeva and
Scott 2001: 118). The Red Tree contains collaged spreads to juxtapose images in startling and violent ways to highlight the irrationality of modern life. The collage technique is the art of resembling fragments of pre-existing images in such a way to form a new image. It can be considered as a subversive form of art that enhances disruption and rapture.

Postmodern picturebooks rupture the conventional and shatter the linear narrative. Trites emphasizes the notion of the subversion of linear narratives that empowers the reader:

In allowing the reader to synthesize information from disparate planes of signification, manifold narratives emphasize the process of reading to subvert traditional linear readings. When no single interpretation asserts itself on the readers, they are more likely to escape the type of ideological manipulation that totalizing texts produce. Manifold narratives allow the reading subject to suture in a nonlinear way that may escape the prescribed limitations of the dominant ideology. (Italics mine, 239-40)

Lewis states that "[n]evertheless the attempt must be made for we are all prone to forget that in the end there is no such thing as 'the text itself', an objective artefact that can be discovered outside of any reading of it. If all we ever do is reflecting upon our own reading we will never find out anything about the text as realized by the child" (1996:113), a point manifested in the following hybrid spread: 


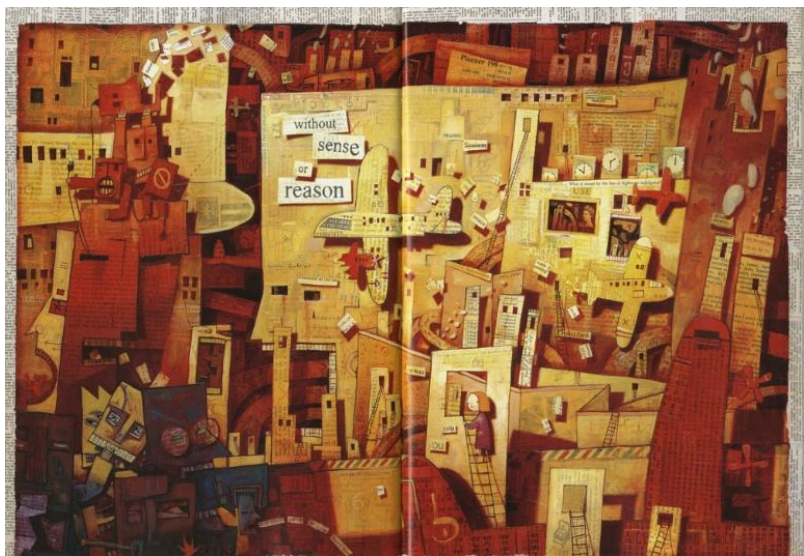

Figure 11

The double spread is busy made of collage from stamps, textbooks, math homework, newspaper, numerals and Asiatic languages. The illustration seems nonsense, coherently illogical, irregular and disoriented. This is intensified by the girl's endeavor to climb a ladder to reach a window that leads nowhere. The aesthetics of collage lies in its capacity to generate flow of multiple and contradictory images as in hallucinations. This is typical of a postmodern picturebook that depicts a world full of contradictions to stimulate the child reader to adopt a plurality of discourses. This is attributed to the nature of postmodern itself that is no longer a whole or autonomous, "but a process perpetually in construction, perpetually contradiction, perpetually open to change" (Italics mine, Moss 55). Hutcheon suggests that metafiction can urge postmodern reading practices: "Its central paradox for readers is that, while being made aware of the linguistic and fictive nature of what is being read, and thereby distanced from any unself-conscious identification on the level of character or plot, readers of metafiction are at the same time made mindful of their active role in reading" (xii). The laudable point is to set the link between metafiction and indeterminacy, a point discussed by Iser:

Gaps are bound to open up, and offer a free play of interpretation for the specific way in which the various views can be connected with one another. These gaps give the reader a chance to build his own bridges, relating the different aspects of the object which have thus far been revealed to him. It is quite impossible for the text itself to fill in the gaps. (Italics mine, 229)

Iser's claim - the reader should fill in textual gaps - concords with Hutcheon's view that the reader of metafictive texts must participate in the meaning-making. In the same line of thought, Lewis believes that the child's view is important even if it is difficult to interpret. 


\section{Recapitulations}

The Red Tree displays some means of surreal transportation such as a colorful papery airplane, a fragile boat, ladders and exhibits endless roads in vast green regions, yet the girl goes back to her small room at the end of her journey. The circular visual narrative shatters nonlinearity and asserts the ideas that the girl's journey endlessly continues. This underlies that the quest of self-discovery is an inner journey within the self. The red-haired girl is entrapped in her nihilistic self and redemption only lies in her ability to foresee hope and pursue it. The color-scheme relies on the use of dark reds, yellows and blues to signify social injustice or child abuse as well as to maintain an eerie feeling and determine the girl's dull mood in a puzzling sepia delineated world since dark values are usually associated with gloomier themes.

Musical and scientific metaphors have been employed to describe the pictoriallexical association. Cech utilizes the "duet" (118) while Pullman underscores the term "counterpoint" (167). Ward and Fox refer to the "contrapuntal" (21) relationship and Ahlberg highlights the "antiphonal" (21). Within the scientific realm, Miller manipulates the idea of "interference" (95) from wave theory describing how two different wave patterns may combine to form a complex new pattern. Moeibus uses geological imagery to speak of the "plate tectonics" (143) of text-image relationship. Within the paradigm of semiotic descriptions, David Lewis uses the notion of "polysystemy" (1996: 105) that explains the piecing together of text out of different kinds of signifying systems. Nodelman employs the term "irony" (1988: 221) to show how words and pictures comment ironically on each other. Schwarcz conceives of two categories which are "congruency" and "deviation". The former shows the harmonious relationship between the visual and the verbal narratives in which pictures complement the text by "running ahead the text and pushing the action forward" while the latter reveals how the illustrations "veer away from the text by opposing it in some way (15). Deviation also describes the association as "counterpoint" when the illustrations tell a different story from the text. Herein lies the enjoyment and pleasures of picturebooks that invite the child reader to become critical interpreters.

Briefly, The Red Tree is a "writerly text" since it invites the child reader to invest themselves in "experiencing, understanding and interpreting Tan's polysemous picturebook" (Pantaleo 272). The brevity of the text constrains the development of the storyline; yet, it is developed and counterpointed by fragmented and ambiguous illustrations that cannot be visualized in a sequential 'realist' manner so as to invite 'active participants' to be involved in an impressionistic tale. The best way of approaching a postmodern picturebook is to go backward and forward and this creates the effect of "loosening the tyranny of the one-way flow" (Pullman 171).

\section{Conclusion}

The current study aims at developing aesthetic appreciation of art and beauty through the act of 'picturing' Tan's The Red Tree as a postmodern picturebook to pinpoint the text rhythm, color-scheme and paratextual conventions. The composite nature of the picturebook is the 
most remarkable aspect to tell the same story with two different, yet interacted modes. Nodelman believes that every picture-book tells at least three stories; a verbal one, a visual one, and a third one that "tends to emerge from ironies created by differences between the first two" (1996: 2). He also examines the tension between the way the pictures stipulate the child reader to discontinue the storyline and the way the words urge the child reader to move on. Moreover, the current paper follows David Lewis's visual 'ecology' to 'picture' the counterpointing interaction between the visuals and the text offers a "reading path" - to use Kress's expression (160) - to decipher the abstract statements visualized surrealistically and "ripe with echoes, allusions and unplumbed depths which the reader proves over and over again, each time discovering something new" (ElTamami 39). Nodelman speculates that words and pictures can never simply parallel or repeat each other due to the inherent differences between the verbal and visual mode of communication and as a result the association between pictures and texts tends to be 'ironic'; "each speaks about matters on which the other is silent" (1996: 221) while in the case of counterpointing interaction, words and images generate meanings "beyond the scope of either one alone" ((Nikolajeva and Scott 2000: 226). The Red Tree is an example of hermeneutic circle that represents a to-and-fro movement between the text and the image to 'picture' salient features. The word-picture interaction is characterized by enhancement and even counterpoint since the picture and the text tell quite diverging stories. Finally, on reviewing the evolution of picture-books, it is obvious that the art of postmodern picturebooks will continue to develop either in form and content to reflect the needs of societies that have shown great interest in technology - the era of digital literacy, e-book, picturebook apps and ereaders. Although some postmodern picturebooks are often short, they have a tremendous potential of being sophisticated and insightful. This is attributed to its inclination to reject "essentialist thinking" (Thacker \& Webb 140) as exemplified in Tan's idiosyncratic artwork which exhibits wild imagination, intricate surreal imagery, dense fragmented visuals, vague and minimal thread of text, absence of a single meaning and mysterious landscapes to toy with the concept of 'plural' postmodern picturebook that combines a multitude of forms and genres. 


\section{Works Cited}

Ahlberg, Allen. "A certain Particularity: An Interview with Janet and Allen Ahlberg". Signal, Vol. 61(Spring/Summer), 1990, pp. 20-26.

Allan, Cherie. Playing with Picturebooks: Postmodernism and the Postmodernesque. Palgrave: Macmillan, 2012.

Anstey, Michele. "'It's not All Black and White': Postmodern Picture Books and New Literacies". Journal of Adolescent and Adult Literacy Vol. 45 (6), 2002, pp. 444457.

Bader, Barbara. American Picture Books from Noah's Ark to the Beast Within. New York: Macmillan, 1976.

Barthes, Roland. "From Work to Text". In The Norton Anthology of Theory and Criticism. Vincent B. Leitch (ed.). New York: Norton, 2001, pp. 1470-1475.

Bauman, Zygmunt. Intimations of Postmodernity. London: Routledge, 1992.

Cech, John. "Remembering Caldecott: The Three Jovial Huntsman and the Art of Picture book", The Lion and the Unicorn, Vol. 84, 1983, pp. 110-119.

Coats, Karen. "Postmodern Picturebooks and the Transmodern Self". In Postmodern Picturebooks: Play, Parody, and Self-referentiality. Lawrence R. Sipe and Sylvia Pantaleo (eds.). New York: Routledge, 2008, pp. 75-88.

Derrida, Jacques. Dissemination. B. Johnson (trans.). Chicago: University of Chicago Press, 1981.

Devos, Lien. "Not all that's Modern is Post: Shaun Tan's Grand Narrative". Bookbird: A Journal of International Children's Literature 49 (4), 2011, pp. 17-23.

Dresang, Eliza. Radical Change: Books for Youth in a Digital Age. New York: H.W. Wilson, 1999.

El-Tamami, Wiam. "The Simple Little Picture Book: Private Theater To Postmodern Experience". Alif: Journal of Comparative Poetics. Vol. 27, Annual, 2007, pp. 2543.

Genova, Judith. "The Significance of Style". Journal of Aesthetics and Art Criticism, Vol. 37 (3), 1979, pp. 315-324.

Genette, Gerard. Paratexts: Thresholds of Interpretation. J. e. Lewin (trans.). Cambridge: Cambridge University Press, 1987.

Goldstone, Bette. "Whaz Up With Our Books? Changing Picture Book Codes and Teaching Implications". The Reading Teacher Vol. 55(4), 2000, pp. 362-370.

Higonnet, Margaret. "The Playground of the Peritext". Children's Literature Association Quarterly, Vol. 15, 2000, pp. 47-49. 
Hunter, Linnet. "The Artist as Narrator: Shaun Tan's Wondrous Worlds". Bookbird: A Journal of International Children's Literature, Vol. 49 (4), 2011, pp. 10-16.

Hutcheon, Linda. Narcissistic Narrative: The Metafictional Paradox. New York \& London: Routledge, 1984.

Iser, Wolfgang. "Indeterminacy and the Reader's Response". In Twentieth Century Literary Theory: A Reader, K.M. Newton (ed.), Hampshire \& London: The Macmillan Press, 1988, pp. 226-231.

Jewitt, Carey \& van Leeuween, Theo. Handbook of Visual Analysis. London: Sage, 2001.

Kiefer, Barbara. "Visual Criticism and Children's Literature". In Evaluating Children's Books: A Critical Look: Aesthetic, Social and Political Aspects of Analyzing and Using Children's Books, B. Hearne \& R. Sutton (eds.), Urbana-Champaign, IL: University of Illinois Graduate School of Library and Information Science, 1993, pp. 73-91.

Kiefer, Barbara."What is a Picturebook Anyway?: The Evolution of Form and Substance through the Postmodern Era and Beyond". In Postmodern Pictures, Lawrence Sipe and Sylvia Pantaleo (eds.), London: Routledge, 2008.

Kress, Gunter. Literacy in the New Media Age. London: Routledge, 2003.

Landes, S. "Picturebooks as literature". Children's Literature Association Quarterly, Vol. 10 (2), 1985, pp. 51-54.

Langer, Suzanne. Feeling and Form. New York: Scribner, 1953.

Lewis, David. "The Constructedness of Texts: Picture Books and the Metafictive". Signal, Vol. 62, 1990, pp. 131-146.

Lewis, David. "Going along with Mr. Gumpy: Polysytemy and Play in the Modern Picturebook", Signal, Vol. 80, 1996, pp. 105-119.

Lewis, David. Reading Contemporary Picturebooks: London: Routledge, 2001.

Lyotard, Jean-François. The Postmodern Condition: A Report On Knowledge. Manchester: Manchester University Press, 1979.

Lyotard, et al.. Nihilism in Postmodernity. Aurora, Colorado: Ashley Woodward, 2009.

Mackey, Margaret. "Postmodern Picturebooks And The Material Conditions of Reading". In Postmodern Picturebooks: Play, Parody, and Self-referentiality, Lawrence R. Sipe and Sylvia Pantaleo (eds.). New York: Routledge, 2008, pp. 103-16.

Marantz, Kenneth. "The Picture Book as Art Object: A Call for Ballanced Reviewing". Wilson Library Bulletin, Vol. 52 (2), 1977, pp. 148-151.

McHale, Brian. Postmodernist Fiction. New York \& London: Routledge, 1987.

Miller, J. H . Illustration. Cambridge, MA: Harvard University Press, 1992. 
Moebius, W . "Introduction to Picturebook Codes". Word and Image, Vol. 2 (2), 1986, pp. 141-158.

Moss, Geoff. "Metafiction, Illustration, and the Poetics of Children's Literature". In P. Hunt (ed.), Literature for Children: Contemporary Criticism, pp. 44-66. New York \& London: Routledge, 1992.

Nikolajeva, Maria \& Scott, Carole. "The Dynamics of Picture Book: Communication". Children's Literature in Education, Vol. 31, 2000, pp. 225-239.

Nikolajeva, M. \& Scott, Carole. How Picturebooks Work. New York: Garland, 2001.

Nodelman, Perry. Words About Pictures: The Narrative Art of Children's Picture Books. Athens and London: The University of Georgia Press, 1988.

Nodelman, Perry. "Illustrations and Picture Books". International Encyclopedia of Children's Literature, Peter Hunter (ed.). London: Routledge, 1996, pp. 113-124.

Nodelman, Perry. "The Implied Viewer: Some Speculations about What Children's Picture Books Invite Reader to Do and Be". CREArtA, Vol. 1 (1), 2000, pp. 23-43.

Nodelman, Perry. The Hidden Adult: Defining Children's Literature. Baltimore, Md,: Johns Hopkins University Press, 2008.

Nodelman, Perry, \& Reimer, Mavis. The Pleasures of Children's Literature. Boston: Allyn and Bacon, 2003.

Novitz, David. "Conventions and the Growth of Pictorial Style". British Journal of Aesthetics, Vol. 16 (4), 1976, pp. 324-337.

Pantaleo, Sylvia. "Filling The Gaps: Exploring the Writerly Metaphors in Shaun Tan's The Red Tree". In Challenging and Controversial Children's Books: Creative and Critical Responses to Visuals Texts, Janet Evans (ed.). New York: Routledge, 2015.

Poesio, C. "The Rhythm of Images". Simonetta Sambotta (trans.). The Lion and The Unicorn. Vol. 26 (2), April, 2002, pp. 223-235.

Pullman, P. "Invisible Pictures", Signal, vol. 60, 1989, pp. 160-186.

Reynolds, Kimberley. Radical Children's Literature: Future Visions and Aesthetic Transformations in Juvenile Fiction. Basingstoke: Palgrave Macmillan, 2007.

Rice, Patricia \& Waugh, Philip (eds.). Modern Literary Theory: A Reader. London \& New York, Auckland \& Melbourne: Edward Arnold, 1994.

Rosenblatt, Louis. The Reader, The Text, The Poem: The Transactional Theory of the Literary Work. Carbondale, IL: Southern Illinois University Press, 1978.

Schwarcz, Joseph. Ways of the Illustrator: Visual Communication in Children's Literature. Chicago: American Library Association, 1982. 
Serafani, Frank \& Clausen, Jennifer. "Considering Typography as a Semiotic Resource in Contemporary Picturebooks". Journal of Visual Literacy, Vol. 31 (2), 2012, pp. 22-38.

Sim, Stuart. The Routledge Companion to Postmodernism. London: Routledge, 2011.

Sipe, Lawrence. "How Picture Books Work: A Semiotic Framed Theory of Text-Picture Relationships". Children's Literature in Education Vol. 29 (2), 1998, pp. 97-108.

Sipe, Lawrence. "Picturebooks as Aesthetic Objects". Literacy Teaching and Learning, Vol. 6 (1), 2001, pp. 23-42.

Stephens, John. Language and Ideology in Children's Fiction. London \& New York: Longman, 1992.

Tan, Shaun. The Red Tree. Sydney: Lothian, 2001.

Tan, Shaun. "The Accidental Graphic Novelist". Bookbird, Vol. 49 (4), October, 2011, pp. $1-9$.

Thacker, Deborah \& Webb, Jean. Introducing Children's Literature: From Romanticism to Postmodernism. London: Routledge, 2002.

Trites, Seelinger. "Manifold Narratives: Metafiction and Ideology in Picture Books". Children's Literature in Education. Vol. 25 (4), 1994, pp. 225-242.

Ward, J and Fox, M. "A Look at Some Outstanding Illustrated books for Children". Children's Literature Association Quarterly, Vol. 9 (1), 1984, pp. 19-21.

Waugh, Patricia. Metafiction: The Theory and Practice Of Self-Conscious Fiction. London: Routledge, 1984. 